\title{
Biodegradation of gas-phase styrene using the fungus Sporothrix variecibatus: Impact of pollutant load and transient operation
}

\author{
Eldon R. Rene, María C. Veiga, Christian Kennes \\ Chemosphere, Volume 79, Issue 2, March 2010, Pages 221-227 \\ DOI: 10.1016/j.chemosphere.2010.01.036
}

\begin{abstract}
Biofiltration of gas-phase styrene was studied using a newly isolated fungus Sporothrix variecibatus, in a perlite biofilter, at inlet concentrations and gas-flow rates ranging from 0.13 to $14 \mathrm{~g} \mathrm{~m}^{-3}$ and 0.075 to $0.34 \mathrm{~m}^{3} \mathrm{~h}^{-1}$, respectively, corresponding to empty bed residence times (EBRT) ranging between 91 and $20 \mathrm{~s}$. Styrene loading rates were varied between 50 and $845 \mathrm{~g} \mathrm{~m}^{-3} \mathrm{~h}^{-1}$ and a maximum elimination capacity of $336 \mathrm{~g} \mathrm{~m}^{-3} \mathrm{~h}^{-1}$ was attained with nearly $65 \%$ styrene removal. On the other hand, the critical inlet loads to achieve more than 90\% removal were 301, 240 and $92 \mathrm{~g} \mathrm{~m}^{-3} \mathrm{~h}^{-1}$ for EBRT of 91, 40, and $20 \mathrm{~s}$, respectively. In order to test the stability and shock bearing capacity of the fungal biofilter, short-term tests were conducted by suddenly increasing the gas-phase styrene concentration, while maintaining the gas-flow rate constant. The response, a restoration in the removal performance to previous high values, after subjecting the biofilter to shock loads proves the resilient nature of the attached Sporothrix sp. and its suitability for biofiltration under non-steady state conditions.
\end{abstract}

\section{Keywords}

Fungal biofilter; Styrene; Sporothrix variecibatus; Loading rate; Shock load

\section{Introduction}

Biofiltration, using bacterial or fungal biocatalysts, has shown to be effective and safe for the treatment of several volatile organic compounds (VOCs) at moderately high flow rates (Kennes and Veiga, 2001, Kennes et al., 2009a and Kennes et al., 2009b). In continuation of our concerted efforts to develop active and versatile fungal biofilters, the current research was undertaken. The main advantage of fomenting fungal rather than bacterial growth for the biofiltration of hydrophobic VOCs like styrene is their ability to completely mineralize these compounds under extreme environmental conditions such as $\mathrm{pH}$ fluctuations, low water content and limited nutrient concentration (Kennes and Veiga, 2004). Fungal biofilters have proven to be more resistant to mild acidification and dry conditions than bacterial biofilters (van Groenestijn et al., 2001). Besides, conventional biofilters inoculated with mixed bacterial cultures face commonly reported operational problems like filter bed compaction, acidification and media drying. This would lead to reduced biofilter performance during the treatment of VOCs.

Research pertaining to the application of fungal biofilters to treat VOCs was initiated only recently. The ability of filamentous fungi to use non-oxygenated aromatic compounds as sole carbon source and to completely mineralize them was also only 
proven recently (Kennes and Veiga, 2004). The easily biodegradable toluene has been the favourite among researchers who have investigated new fungal isolates, though mixtures of other VOCs containing toluene have also been reported. One of the most extensively studied organism belongs to the genus Exophiala, although strains of Scedosporium, Fusarium, Paecilomyces, Cladosporium, Cladophialophora, Pleurotus, Trametes, Bjerkandera and Phanerochaete have also been used to treat gas-phase VOCs ( Kennes and Veiga, 2004). In a previous work, styrene removal was tested in a continuously operating biofilter to estimate both steady state and non-steady state performance, using mixed cultures, achieving an elimination capacity $(E C)$ value of $382 \mathrm{~g} \mathrm{~m}^{-3} \mathrm{~h}^{-1}$, with a removal efficiency $(R E)$ of $82 \%$ ( Rene et al., 2009a and Rene et al., 2009b). In that study, the dominant fungal species was later isolated and identified as Sporothrix variecibatus, a white-coloured yeast-like thermally dimorphic fungus. Fungi are more suitable for treating hydrophobic VOCs in biofilters because the larger surface area of hyphae would enhance the absorption and transport of hydrophobic compounds from the contaminated phase to the cell surface. It was shown that gas/mycelium contact surface was increased by adding perlite ( Braun-Lullemann et al., 1997). Sporothrix spp. are characterized as conidiogenous cells that arise laterally or terminally from any place on the hypha, bearing one-celled conidia on sympodially developing denticles ( Aghayeva et al., 2004). That genus is paraphyletic and includes species of both ascomycetes and basidiomycetes ( de Hoog, 1999).

This paper reports the performance of a perlite biofilter inoculated with $S$. variecibatus and tested at different empty bed residence times (EBRT) and under different styrene loading conditions through long-term steady state and short-term non-steady state (transient) lab-scale experiments.

\section{Materials and methods}

\subsection{Microorganism and media composition}

The fungus, S. variecibatus, was grown and maintained in a sterile atmosphere on $15 \mathrm{~g}_{\text {agar }} \mathrm{L}^{-1}$, under ambient conditions. The culture medium was autoclaved at $120^{\circ} \mathrm{C}$ for $20 \mathrm{~min}$ before adding the filter-sterilized solutions of vitamins and trace minerals. $1 \mathrm{~g}$ oxyacetylene was aseptically added to $1 \mathrm{~L}$ of sterilized agar medium to prevent the growth of any bacterial colony. The petri dish containing the agar medium and styrene utilizing fungus were incubated in a dessicator, in the presence of styrene vapour, supplied as the sole carbon source for fungal growth. The composition of the culture medium used in the biofiltration studies was as described earlier ( Kennes et al., 1996).

\subsection{Preparation of initial inoculum for continuous experiments}

S. variecibatus was grown in two $1000 \mathrm{~mL}$ air-tight Erlenmeyer flasks (working volume of $250 \mathrm{~mL}$ ) on styrene, having an initial gas-phase concentration of about $15 \mathrm{~g} \mathrm{~m}^{-3}$ at $30{ }^{\circ} \mathrm{C}$ and at constant shaking at $175 \mathrm{rpm}$. After reaching an optical density (OD) of 0.8 at $600 \mathrm{~nm}$, the cells were harvested by centrifugation at $5000 \mathrm{rpm}$ for $20 \mathrm{~min}$ and resuspended in $2 \mathrm{~L}$ fresh medium to be used as inoculum for the continuous biofilter. This culture was aseptically added to the biofilter from the top, the leachate then drained after $4 \mathrm{~h}$ and re-supplied several times till visible biomass was noticed on the perlite surface. 


\subsection{Biofilter setup and operation}

The schematic of the lab-scale biofilter is shown in Fig. 1, and its operational characteristics are similar as described elsewhere (Rene et al., 2009a). The packing in the biofilter consisted of $1.9 \mathrm{~L}$ sieved perlite particles $(4-6 \mathrm{~mm})$ and the reactor was operated in a down-flow mode (ID-10 cm, bed height- $24 \mathrm{~cm}$ ). Apart from inlet and outlet gas sampling ports, for estimating the changes in styrene and $\mathrm{CO}_{2}$ concentrations, the biofilter was fitted with one side-port at the middle of the biofilter height to periodically withdraw perlite samples for estimating the changes in biomass concentration. The bed's moisture content was maintained constant by periodic addition (once every $3 \mathrm{~d}$ ) of fresh mineral salt medium. The pressure drop across the biofilter was measured using a differential U-tube water manometer connected to the top and bottom section, with the operational range of $0-40 \mathrm{~cm} \mathrm{H}_{2} \mathrm{O}$.
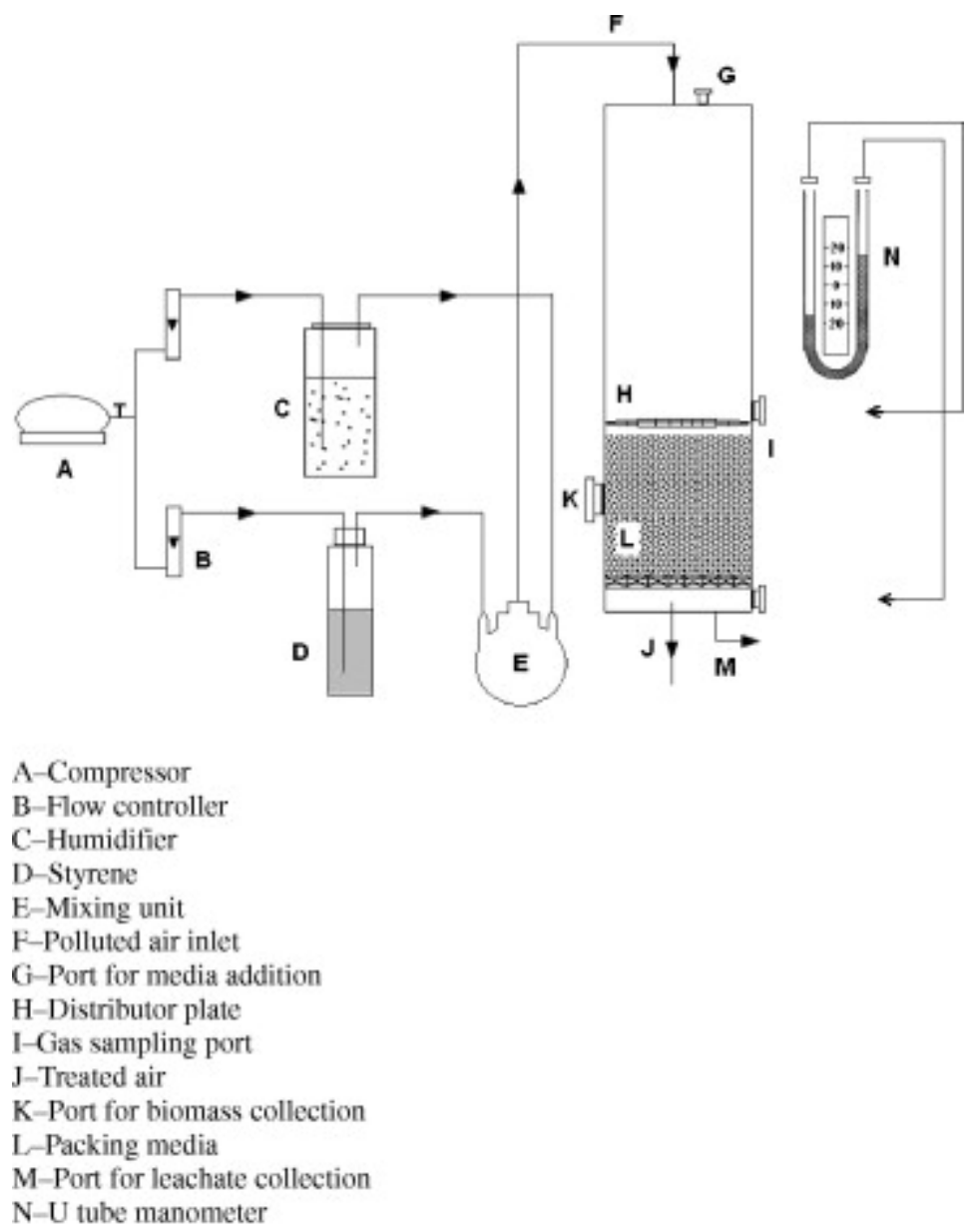

Fig. 1.

Schematic of the fungal biofilter.

\subsection{Analytical methods}

A Crison model $507 \mathrm{pH}$ meter, connected to an Ingold electrode was used for measuring the $\mathrm{pH}$. Biomass weight was estimated by measuring the $\mathrm{OD}$, and a standard calibration line was plotted based on the relationship between dry weight and OD. The absorbance $(\lambda=600 \mathrm{~nm})$ of the liquid cultures, corresponding to the growth of $S$. variecibatus with styrene as the carbon source, was measured by using a UV-Vis spectrophotometer 
(Hitachi, Model U-200, Pacisa \& Giralt, Madrid, Spain). Biomass concentration in the biofilter, as $g$ of dry biomass $\mathrm{g}^{-1}$ of perlite and moisture content (\%) were measured according to the procedure outlined by Mohammad et al. (2007). Gas samples were analyzed on a HP 5890 gas chromatograph, using a $50 \mathrm{~m}$ TRACER column and a FID. The flow rates were $30 \mathrm{~mL} \mathrm{~min}^{-1}$ for $\mathrm{H}_{2}$ and $300 \mathrm{~mL} \mathrm{~min}^{-1}$ for air. Helium was used as the carrier gas at a flow rate of $2 \mathrm{~mL} \mathrm{~min}^{-1}$. The temperatures at the GC injection, oven and detection ports were 250, 120 and $250{ }^{\circ} \mathrm{C}$, respectively. $\mathrm{CO}_{2}$ was analyzed with a HP 5890 gas chromatograph equipped with a thermal conductivity detector (TCD). The injection and oven temperatures were 90 and $25^{\circ} \mathrm{C}$ respectively, with the TCD set at $100{ }^{\circ} \mathrm{C}$. Perlite samples that contain the immobilized $S$. variecibatus were prepared for observations under the electron microscope according to the procedure described by Jin et al. (2005). Examinations were performed with a JEOL JSM-6400 SEM working at a voltage of $20 \mathrm{kV}$ and a working distance of $15 \mathrm{~mm}$, and with Oxford Instruments EDX equipment.

\section{Results and discussion}

\subsection{Impact of styrene concentration and EBRT on biofilter performance}

After acclimation, experiments were carried out in three different phases at different EBRT, i.e. 91.2 s (days 1-51), 40.2 s (days 52-80), and 20.1 s (days 81-109).

\subsection{Phase I: $\mathrm{EBRT}=91.2 \mathrm{~s}$}

Fig. 2 shows the $R E$ profiles as a function of the inlet styrene concentration. After reaching stable $R E$, the styrene concentration was increased on a daily basis on the 16 th d, from 1.1 to $2.7 \mathrm{~g} \mathrm{~m}^{-3}$, while the $R E$ dropped from $>95 \%$ to about $75 \%$. However, when the concentration was further increased and maintained constant for several days (days 23-31) at $4 \mathrm{~g} \mathrm{~m}^{-3}$, the $R E$ slowly increased and reached almost $100 \%$. In order to estimate the maximum removal performance of the fungal biofilter, the concentration was thereafter further increased to as high as $14 \mathrm{~g} \mathrm{~m}^{-3}$ (days 33-50). Although such concentration is quite high for gas-phase biofiltration, it was used to allow comparison of results at high loads at this EBRT with results obtained at similar loads but lower EBRT and thus lower concentrations $\left(<4-5 \mathrm{~g} \mathrm{~m}^{-3}\right)$. It was observed that, for concentrations lower than $7.6 \mathrm{~g} \mathrm{~m}^{-3}$ and at an EBRT of $91.2 \mathrm{~s}, R E>80 \%$ could be maintained in the biofilter. Conversely, concentrations $>8 \mathrm{~g} \mathrm{~m}^{-3}$ led to a rapid drop in the $R E$, from $>80 \%$ to $50 \%$. The $\mathrm{pH}$ of the leachate was also monitored periodically. During the previous step increase in concentrations, the $\mathrm{pH}$ dropped from an initial value of 5.9-4.2, while in the second step increase and for inlet styrene concentrations $>8 \mathrm{~g} \mathrm{~m}^{-3}$, the $\mathrm{pH}$ was 3.5. Apparently, these low $\mathrm{pH}$ values did not influence the reactor's performance at high substrate concentrations, presumably because of the resistance of the Sporothrix sp. to low $\mathrm{pH}$ values. Indeed, fungal biofilters are expected to resist mild acidification, and also in some instance acidification has proven to be advantageous ( van Groenestijn et al., 2001 and Qi and Moe, 2006). Thus, during the first phase of operation, though the range of styrene concentrations tested was quite high for conventional biofilters, a stable removal efficiency, $>86 \%$, was shown plausible in this fungal biofilter for styrene concentrations less than $6.5 \mathrm{~g} \mathrm{~m}^{-3} \mathrm{~h}^{-1}$. 


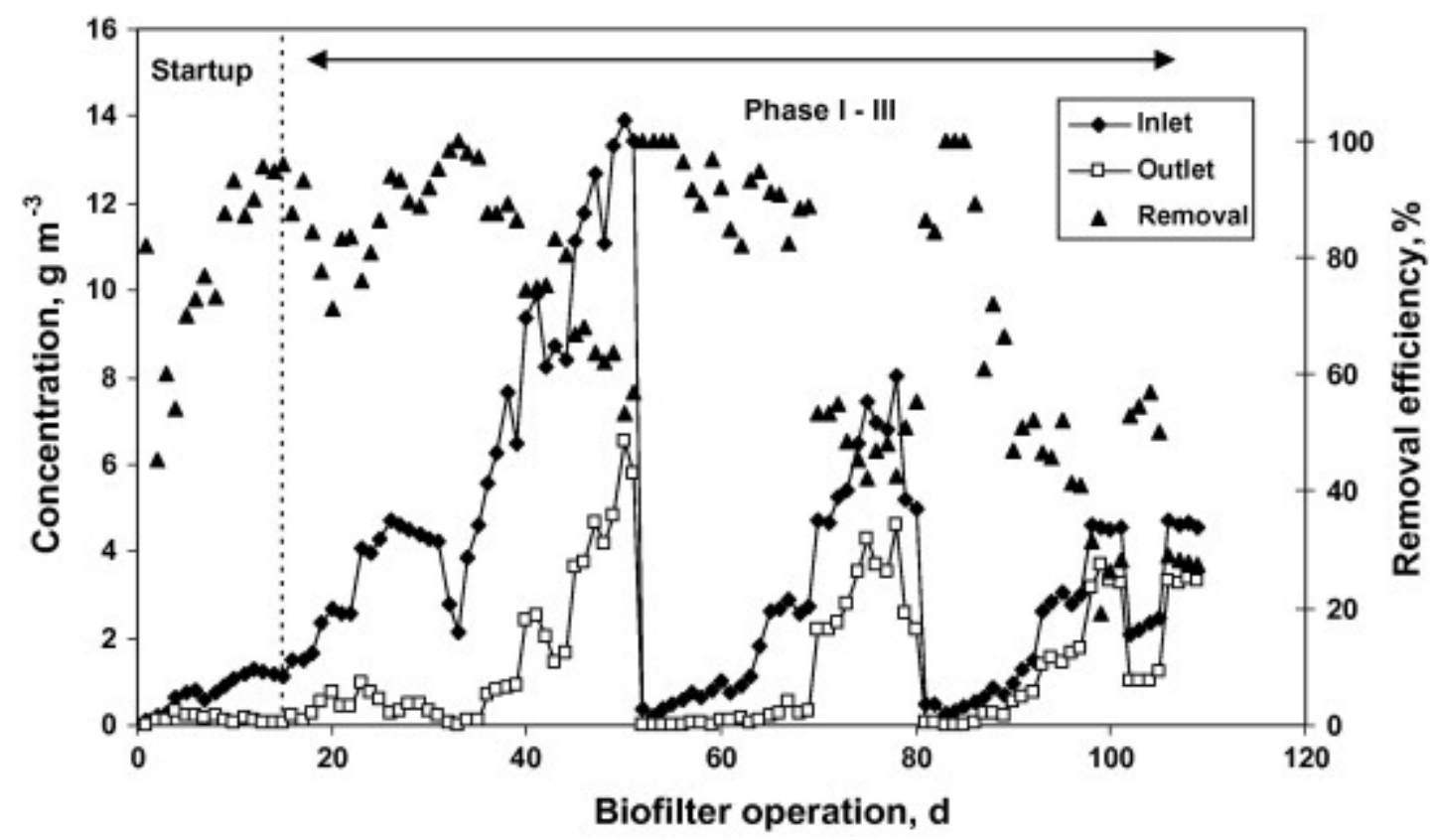

Fig. 2.

Removal of gas-phase styrene in the fungal biofilter.

\subsection{Phase II: $\mathrm{EBRT}=40.2 \mathrm{~s}$}

As evident from Fig. 2, during this phase, for the first $10 \mathrm{~d}$, the concentration of styrene was again set at relatively low values $\left(<1.1 \mathrm{~g} \mathrm{~m}^{-3}\right)$, while the flow rate was maintained constant at $0.17 \mathrm{~m}^{3} \mathrm{~h}^{-1}$. This was done to improve the removal performance of the biofilter and recuperate the activity of the fungal biocatalyst, that was earlier subjected to high gas-phase styrene concentrations in phase-I. The $R E$ remained $>90 \%$ during these initial $10 \mathrm{~d}$. Later, in two successive steps, the concentration was increased to envisage the maximum biofilter performance attainable at this EBRT. Though a high $R E$ was maintained ( $>80 \%$ ) during the first step increase to $2.8 \mathrm{~g} \mathrm{~m}^{-3}$, a further increase in the concentration from 2.8 to $8 \mathrm{~g} \mathrm{~m}^{-3}$, showed a systematic declining profile in the $R E$. At the maximum concentration supplied in this phase $\left(8 \mathrm{~g} \mathrm{~m}^{-3}\right)$, the $R E$ was just $42 \%$.

\subsection{Phase III: EBRT $=20.1 \mathrm{~s}$}

Phase-III was performed at lower concentrations $\left(\leqslant 4.5 \mathrm{~g} \mathrm{~m}^{-3}\right)$, yet high gas-flow rates $\left(0.34 \mathrm{~m}^{3} \mathrm{~h}^{-1}\right)$ and lower EBRT, that corresponded to styrene loading rates up to as high as $845 \mathrm{~g} \mathrm{~m}^{-3} \mathrm{~h}^{-1}$. Once again, like in the previous phase, the inlet concentration was reduced and maintained at $<0.9 \mathrm{~g} \mathrm{~m}^{-3}$ for the first $8 \mathrm{~d}$ (Fig. 2). The original reactor performance was easily restored with minor fluctuations (>90\%), and thereafter, when the concentration was increased to $3 \mathrm{~g} \mathrm{~m}^{-3}$, the $R E$ dropped to $45 \%$. A further increase in the concentration to $4.5 \mathrm{~g} \mathrm{~m}^{-3}$, led to an abrupt decline in the $R E$ values. The reactor performance was at its lowest $(<25 \%)$, when the gas-phase styrene concentration reached its highest value $\left(4.5 \mathrm{~g} \mathrm{~m}^{-3}\right)$. Because of the high loading rates in this phase, the removal efficiency dropped significantly. At high loading rates, the $\mathrm{pH}$ of the leachate reduced further, reaching a value as low as 3.1 on the 105th d. 


\subsection{Elimination capacity vs. load}

In waste gas treatment systems, the performance of biofilters and biotrickling filters is highly dependant on the EBRT. Therefore, the maximum EC and critical load clearly dropped when reducing the EBRT as shown in Fig. 3a, and was dependant on the combined effect of pollutant concentration and EBRT ( Fig. 3a and b). The critical load to achieve more than $90 \% R E$ was $301 \mathrm{~g} \mathrm{~m}^{-3} \mathrm{~h}^{-1}$ at an EBRT of $90.1 \mathrm{~s}$, while it dropped to 240 and $92 \mathrm{~g} \mathrm{~m}^{-3} \mathrm{~h}^{-1}$ at EBRT of 40.2 and $20.1 \mathrm{~s}$, respectively.
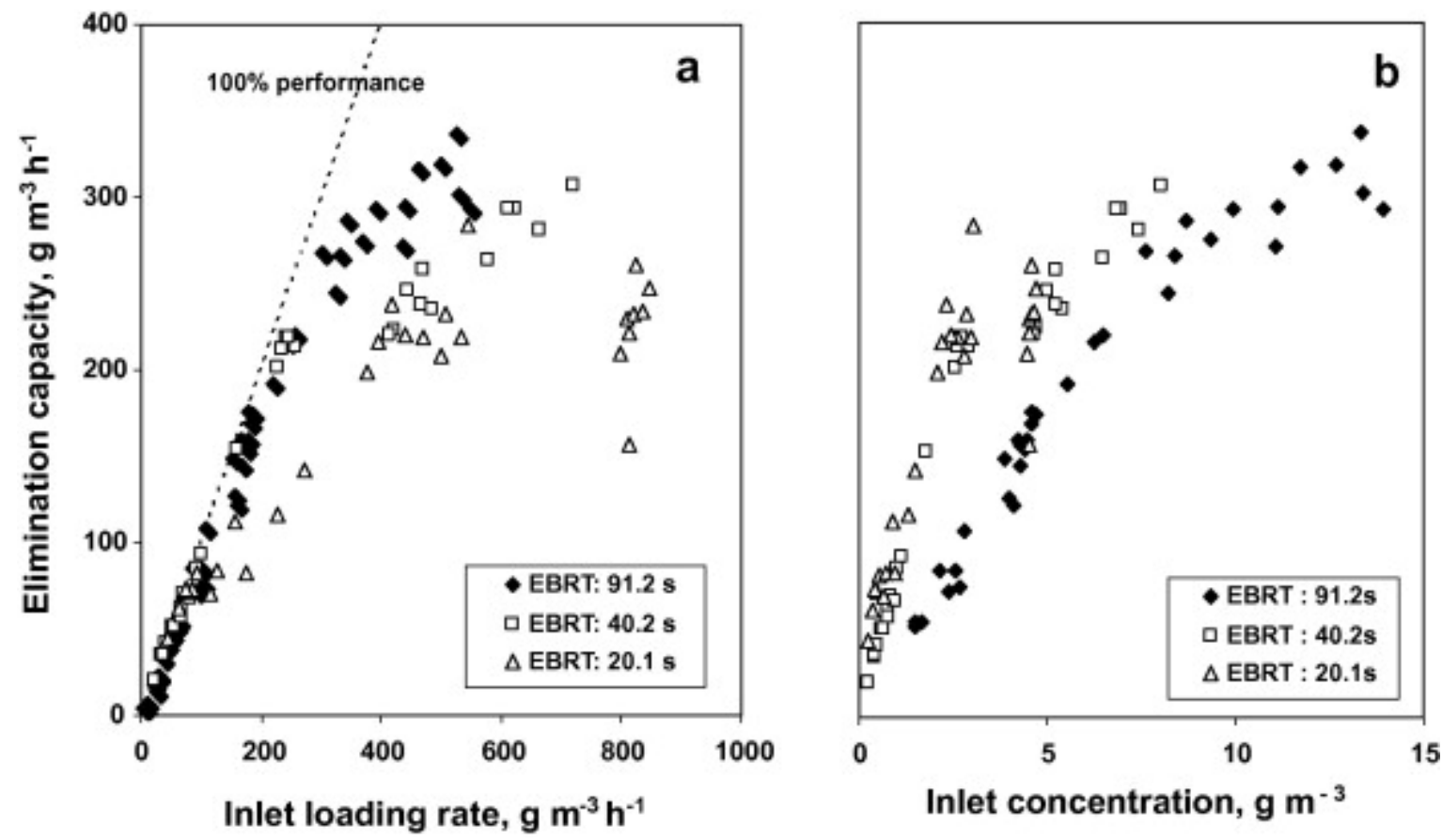

Fig. 3.

Effect of (a) styrene loading rate and (b) concentration on the elimination capacity of the biofilter at different EBRTs.

In this study, a maximum EC of $336 \mathrm{~g} \mathrm{~m}^{-3} \mathrm{~h}^{-1}$ was achieved at an EBRT of $91.2 \mathrm{~s}$, when the inlet loading rate (ILR) was $525 \mathrm{~g} \mathrm{~m}^{-3} \mathrm{~h}^{-1}$. Such maximum $E C$ is rather high and can be attributed to the stable aerial mycelial growth of the fungus $S$. variecibatus and its ability to use perlite as a suitable support matrix. These performance values are also very good compared to other literature reported values on fungal biofilters, where similar organic compounds have been tested ( Table 1). 
Table 1.

Typical EC values reported for fungal biofilters biodegrading Volatile Aromatic Compounds.

\begin{tabular}{|c|c|c|c|c|}
\hline $\begin{array}{l}\text { Original } \\
\text { inoculum }\end{array}$ & Pollutant & $\begin{array}{l}E C_{\max } \\
\left(\mathrm{g} \mathrm{m}^{-3} h^{-1}\right)\end{array}$ & Media & Reference \\
\hline $\begin{array}{l}\text { Exophiala } \\
\text { oligosperma }\end{array}$ & Toluene & 164 & Perlite & \begin{tabular}{|l|}
$\begin{array}{l}\text { Estévez et al. } \\
(2005)\end{array}$ \\
\end{tabular} \\
\hline $\begin{array}{l}\text { Scedosporium } \\
\text { opiospermum }\end{array}$ & Toluene & $220-361^{\mathrm{a}}$ & Vermiculite/GAC & $\begin{array}{l}\text { García-Peña } \\
\text { et al. (2001) }\end{array}$ \\
\hline $\begin{array}{l}\text { Cladophialophora } \\
\text { sp. }\end{array}$ & Toluene & $125^{b}$ & Perlite & \begin{tabular}{|l|}
$\begin{array}{l}\text { Woertz et al. } \\
(2002)\end{array}$ \\
\end{tabular} \\
\hline $\begin{array}{l}\text { Paecilomyces } \\
\text { variotii }\end{array}$ & Toluene & 55 & Perlite & \begin{tabular}{|l|}
$\begin{array}{l}\text { Estévez et al. } \\
(2005)\end{array}$ \\
\end{tabular} \\
\hline $\begin{array}{l}\text { Paecilomyces } \\
\text { variotii }\end{array}$ & Toluene & $290^{c}$ & Ceramic rings & $\begin{array}{l}\text { Aizpuru et al. } \\
(2005)\end{array}$ \\
\hline Phanerochaete sp. & Toluene & 110 & Wood chips & $\begin{array}{|lll|}\begin{array}{l}\text { Jorio et al. } \\
(2009)\end{array} & \\
\end{array}$ \\
\hline Cladosporium sp. & Xylene & 77 & & \\
\hline Non-specific fungi & $\alpha$-Pinene & 24-38 & \begin{tabular}{|lr}
$\begin{array}{l}\text { Perlite, } \\
\text { llay, }\end{array}$ polyurethane \\
foam, compost
\end{tabular} & $\mid \begin{array}{|ll|}\mid \text { Gan } & \\
\text { Groenestijn } \\
\text { and } & \text { Liu } \\
(2002) & \\
\end{array}$ \\
\hline Ophiostoma sp. & $\alpha$-Pinene & 143 & Lava rock & $\begin{array}{ll}\text { Jin et al. } \\
(2006)\end{array}$ \\
\hline $\begin{array}{l}\text { Rhinocladiella } \\
\text { similis }\end{array}$ & Hexane $^{d}$ & 74 & Perlite & $\begin{array}{|ll|}\begin{array}{l}\text { Vigueras } \\
\text { al. (2009) }\end{array} & \text { et } \\
\end{array}$ \\
\hline & Methanol $^{\mathrm{d}}$ & 230 & & \\
\hline & Toluene & 85 & & \\
\hline & Phenol & 30 & & \\
\hline $\begin{array}{l}\text { Exophiala } \\
\text { jeanselmei }\end{array}$ & Styrene & 62 & Perlite & \begin{tabular}{|l} 
Cox et al. \\
$(1997)$
\end{tabular} \\
\hline \begin{tabular}{|l} 
Sporothrix \\
variecibatus
\end{tabular} & Styrene & 336 & Perlite & This study \\
\hline \multicolumn{5}{|l|}{$\begin{array}{l}\text { a } \\
\text { Short term experiments. } \\
\text { b } \\
\text { In the presence of mites. } \\
\text { c } \\
\text { Low water content. } \\
d \text { A } \\
\text { Aliphatic VOCs. }\end{array}$} \\
\hline
\end{tabular}




\subsection{Carbon dioxide, pressure drop and biomass concentration profiles}

The carbon dioxide production rate $\left(\mathrm{P}_{\mathrm{CO} 2}, \mathrm{PCO} 2, \mathrm{~g} \mathrm{~m}^{-3} \mathrm{~h}^{-1}\right)$ in the biofilter was monitored every day, by calculating the difference between the inlet and outlet $\mathrm{CO}_{2}$ concentrations. This can be defined by:

$\mathrm{P}_{\mathrm{CO}_{2}}=\left[\frac{\mathrm{CO}_{2 \text { in }}-\mathrm{CO}_{2, \text { out }}}{\mathrm{CO}_{2 \text { in }}}\right] \times \frac{\mathrm{Q}}{\mathrm{V}}$

Fig. 4a shows the profile of $\mathrm{P}_{\mathrm{CO} 2} \mathrm{PCO} 2$ vs. the $E C$ of the biofilter. For complete oxidation of styrene to $\mathrm{CO}_{2}$ and water, the ratio of mass $\mathrm{CO}_{2}$ produced to the amount of styrene consumed should be 3.4, according to the following stoichiometric reaction:

$\mathrm{C}_{8} \mathrm{H}_{8}+10 \mathrm{O}_{2} \rightarrow 8 \mathrm{CO}_{2}+4 \mathrm{H}_{2} \mathrm{O}$ 

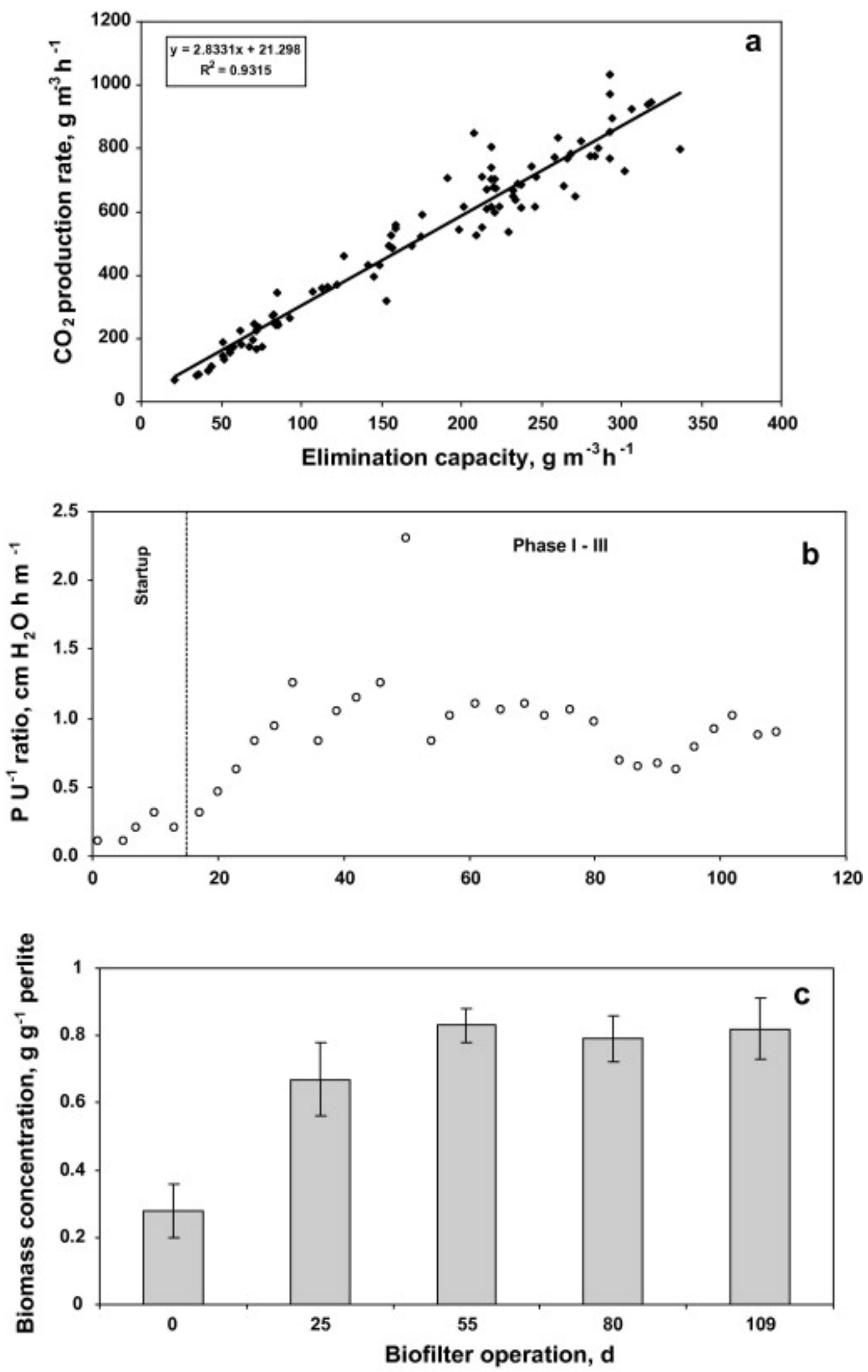

Fig. 4.

Variations of (a) carbon dioxide production rate vs elimination capacity of styrene, (b) pressure drop and (c) biomass concentration in the fungal biofilter. 
However, when biomass growth is taken into account, with ammonium chloride as nitrogen source, $1.27 \mathrm{~g} \mathrm{CO}_{2}$ should be generated for each gram styrene degraded, which can be represented by:

$\mathrm{C}_{8} \mathrm{H}_{8}+5 \mathrm{O}_{2}+\mathrm{NH}_{4} \mathrm{Cl} \rightarrow 3 \mathrm{CO}_{2}+\mathrm{C}_{5} \mathrm{H}_{7} \mathrm{NO}_{2}+\mathrm{HCl}+2 \mathrm{H}_{2} \mathrm{O}$

Here, the average ratio of $\mathrm{CO}_{2}$ produced to the amount of styrene consumed was 2.83, under steady state conditions (Fig. 4a). $\mathrm{CO}_{2}$ recoveries reported in the literature often neglect biomass growth. $\mathrm{CO}_{2}$ production exceeding $100 \%$ is also not unusual in biofilters when endogenous respiration becomes a relevant process.

Pressure drop ( $\Delta P$ ) is directly related to the biomass accumulation in the filter bed. Therefore it has been suggested that the biofilter medium should have high porosity, sufficient moisture holding capacity and resistance to compaction for minimizing $\Delta P$ ( Kennes et al., 2009a and Kennes et al., 2009b). $\Delta P$ across the biofilter height was monitored periodically and the $P \quad U^{-1}$ ratios $(\Delta P / U)$, corresponding to different air velocities $\left(U, \mathrm{~m} \mathrm{~h}^{-1}\right.$ ) were determined ( Morgan-Sagastume et al., 2003). These $P U^{-1}$ ratios profiles are plotted as a function of the biofilter operation time in Fig. 4b. During phase-I, when the styrene load was increased from $60 \mathrm{~g} \mathrm{~m}^{-3} \mathrm{~h}^{-1}$ (day 16) to $530 \mathrm{~g} \mathrm{~m}^{-3} \mathrm{~h}^{-1}$ (day 51), the $\Delta P$ increased 6-fold (2.2 $\mathrm{cm} \mathrm{H}_{2} \mathrm{O}, P \quad U^{-1}=2.3$ ). This can be attributed to the growth of the filamentous fungus that almost grew 3-fold in phase-I from an initial biomass concentration of 0.28 g biomass $\mathrm{g}_{\text {perlite }}^{-1}$ gperlite- 1 in the acclimation phase ( Fig. 4c). In phase-II (day 52-80), the $\Delta P$ values increased further, but the normalized $P \quad U^{-1}$ values were almost constant $\left(1 \mathrm{~cm} \mathrm{H}_{2} \mathrm{O} \mathrm{h} \mathrm{m}{ }^{-1}\right)$, which can be mainly due to an increase in the gas-flow rate, since the biomass concentration remained roughly constant at 0.8 gbiomass $\mathrm{g}_{\text {perlite }}^{-1}$ gperlite- 1 during this phase and no significant filter bed compaction was visually noticed.

In phase-III, when the gas-flow rate was increased further $\left(0.34 \mathrm{~m}^{3} \mathrm{~h}^{-1}\right)$, the $\Delta P$ values were also consistently higher $\left(>3 \mathrm{~cm} \mathrm{H}_{2} \mathrm{O}\right)$ than those observed in the previous two phases, yet the bioreactor performance did not decrease due to an increase in $\Delta P$, instead, the decrease in performance was due to high styrene loading rates. The $P U^{-1}$ value varied between 0.4 and $1.2 \mathrm{~cm} \mathrm{H}_{2} \mathrm{O} \mathrm{h} \mathrm{m}{ }^{-1}$. This observation is not unusual, as such minor increase in $\Delta P$ has not shown to decrease biofilter performance ( Jang et al., 2004), and the $\Delta P$ values observed in this study are well within the safe limits of $\Delta P$ recommended for conventional biofilters ( Kennes and Veiga, 2001).

On the other hand, the biomass concentration measured at the end of phase-III was 0.82 gbiomass $\mathrm{g}_{\text {perlite }}^{-1}$ gperlite- 1 , similar as in phase-II, although loading rates as high as $845 \mathrm{~g} \mathrm{~m}^{-3} \mathrm{~h}^{-1}$ were imparted to the fungal biofilter at an EBRT of $20.1 \mathrm{~s}$. Such observations are not common in mixed culture and bacterial biofilters, where high pollutant loads have shown to induce substrate toxicity effects and therefore decreased biomass concentrations in the filter bed (Rene et al., 2005 and Raghuvanshi and Babu, 2009). 


\subsection{Scanning electron microscopy (SEM)}

SEM images obtained from perlite samples collected after the completion of steady state experiments were closely watched to confirm, if the original Sporothrix $s p$. was present in the biofilter. Fig. 5, shows typical spores and hyphal growth of the Sporothrix strain which confirmed the predominant presence of the original inoculum. Fungi of the genus Sporothrix form chains of spores by repeated budding (blastic conidia) from a conidiogenous cell or fertile hypha ( Heritage et al., 1996). Nevertheless, the inoculated biocatalyst does not need to remain dominant in full-scale systems as long as the performance remains high.
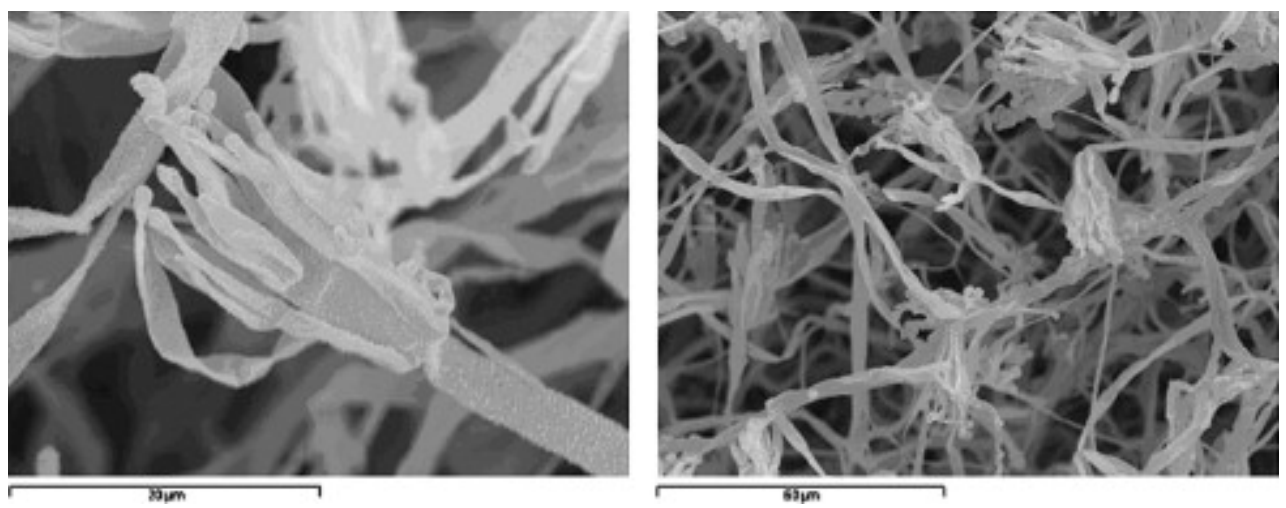

Fig. 5.

SEM images of Sporothrix variecibatus growing on the packing material after long-term operation.

\subsection{Shock loading effects}

Periodic peaks in concentration can be normally expected in any industrial process. The biofilter was subjected to a short-term 6 h-shock load, by increasing the inlet styrene concentration from an initial value of $0.4 \mathrm{~g} \mathrm{~m}^{-3}$ to about $2.5 \mathrm{~g} \mathrm{~m}^{-3}$ during the shock load, at an EBRT of $20.1 \mathrm{~s}$. The biomass concentration was $0.8 \mathrm{~g}$ g perlite gperlite- 1 . Initially, the biofilter was stabilized overnight for $12 \mathrm{~h}$ at low concentration $\left(0.4 \mathrm{~g} \mathrm{~m}^{-3}\right)$ to achieve nearly $100 \%$ removal of styrene. The results shown in Fig. 6, indicate that the styrene laden fungal biofilter was sensitive to fluctuations in loading rate. When the ILR was increased suddenly from 80 to $450 \mathrm{~g} \mathrm{~m}^{-3} \mathrm{~h}^{-1}$, the $R E$ decreased from $100 \%$ to nearly 52\%. The EC, thus remained almost constant at about $220 \mathrm{~g} \mathrm{~m}^{-3} \mathrm{~h}^{-1}$, during shock load. However, when the ILR was brought back to original values, the RE gradually increased and complete restoration of fungal activity in terms of removal performance was observed. Shock loading studies in fungal biofilters are scarce in the literature. Jin et al. (2007) studied shock loading effects during the biodegradation of $\alpha$ pinene in a biofilter inoculated with a Ophiostoma sp. and observed that the fungal biofilter was able to withstand periodic shock loads for more than 1 month of transientstate operations, maintaining $E C$ and $R E$ around $60 \mathrm{~g} \mathrm{~m}^{-3} \mathrm{~h}^{-1}$ and $90 \%$, respectively. The high EC reported in our study for a hydrophobic VOC like styrene $\left(220 \mathrm{~g} \mathrm{~m}^{-3} \mathrm{~h}^{-1}\right)$ during non-steady state operation suggests that the fungal biofilter is quite resistant to shock loads. 


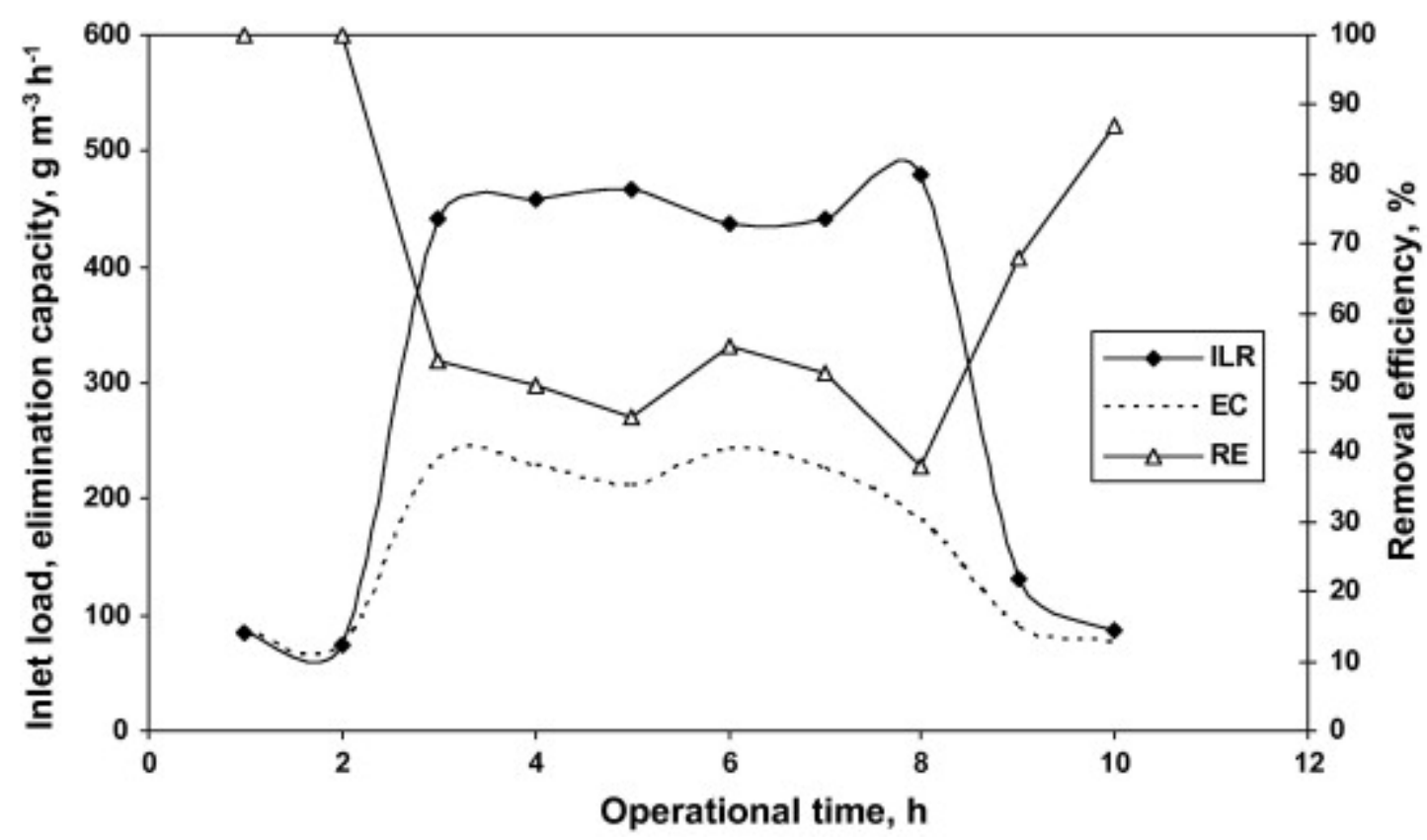

Fig. 6.

Effect of short-term shock load on the performance of the biofilter.

\section{Conclusions}

The critical load to the biofilter was found to decrease from 301 to $92 \mathrm{~g} \mathrm{~m}^{-3} \mathrm{~h}^{-1}$ with a decrease in the EBRT from 91.2 to $20.1 \mathrm{~s}$. Through short-term shock loads, the sensitivity and stability of the fungal biofilter to withstand peak loading conditions was examined. This shock load led to a rapid decline in the $R E$, though high $E C$ were maintained ( $>200 \mathrm{~g} \mathrm{~m}^{-3} \mathrm{~h}^{-1}$ ), and complete recovery to original performance occurred in less than $1 \mathrm{~h}$ when previous loading conditions were restored. SEM images confirmed the predominant presence of the original fungus, even after long-term operations. Overall, the fungal biofilter was found to be robust, versatile and showed no signs of reticence despite variations in loading rates under steady and transient-state conditions.

\section{Acknowledgements}

The authors thank the Spanish Ministry of Science and Innovation (Project: CTM200762700/TECNO), and European FEDER funds for providing financial support to this research. Eldon R. Rene thanks the Ministry of Science and Innovation for his "Juan de La Cierva"-post doctoral research contract. We also acknowledge the collaboration of Radka Spackova and María Montes. 


\section{References}

D.N. Aghayeva, M.J. Wingfield, Z.W. de Beer, T. Kirisits

Two new Ophiostoma species with Sporothrix anamorphs from Austria and Azerbaijan Mycologia, 96 (2004), pp. 866-878

A. Aizpuru, B. Dunat, P. Christen, R. Auria, I. Garcia-Peña, S. Revah

Fungal biofiltration of toluene on ceramic rings

J. Environ. Eng. - ASCE, 131 (2005), pp. 396-402

A. Braun-Lullemann, A. Majcherczyk, A. Huttermann

Degradation of styrene by white-rot fungi

Appl. Microbiol. Biotechnol., 47 (1997), pp. 150-155

H.H.J. Cox, R.E. Moerman, S. van Baalen, W.N.M. van Heiningen, H.J. Doddema, W. Harder

Performance of styrene degrading biofilter containing the yeast Exophiala jeanselmei

Biotechnol. Bioeng., 53 (1997), pp. 259-266

G.S. de Hoog

Ecology and evolution of black yeasts and their relatives

Stud. Mycol., 43 (1999), pp. 1-208

E. Estévez, M.C. Veiga, C. Kennes

Biofiltration of waste gases with the fungi Exophiala oligosperma and Paecilomyces variotii

Appl. Microbiol. Biotechnol., 67 (2005), pp. 563-568

I. García-Peña, S. Hernández, E. Favela-Torres, R. Auria, S. Revah

Toluene biofiltration by the fungus Scedosporium apiospermum TB1

Biotechnol. Bioeng., 76 (2001), pp. 61-69

J. Heritage, E.G.V. Evans, R.A. Killington

Introductory microbiology

Series - Studies in Biology, The Press Syndicate of the University of Cambridge, Cambridge, United Kingdom (1996), p. 18

J.H. Jang, M. Hirai, M. Shoda

Styrene degradation by Pseudomonas sp SR-5 in biofilters with organic and inorganic packing materials

Appl. Microbiol. Biotechnol., 65 (2004), pp. 349-355

Y. Jin, M.C. Veiga, C. Kennes

Autotrophic deodorization of hydrogen sulfide in a biotrickling filter

J. Chem. Technol. Biotechnol., 80 (2005), pp. 998-1004

Y. Jin, M.C. Veiga, C. Kennes

Performance optimization of the fungal biodegradation of $\alpha$-pinene in a gas-phase biofilter

Process Biochem., 41 (2006), pp. 1722-1728 
Y. Jin, L. Guo, M.C. Veiga, C. Kennes

Fungal biofiltration of $\alpha$-pinene: effects of temperature, relative humidity, and transient loads

Biotechnol. Bioeng., 96 (2007), pp. 433-443

H. Jorio, Y. Jin, H. Elmrini, J. Nikiema, R. Brzezinski, M. Heitz

Treatment of VOCs in biofilters inoculated with fungi and microbial consortium

Environ. Technol., 30 (2009), pp. 477-485

C. Kennes, M.C. Veiga

Conventional biofilters

C. Kennes, M.C. Veiga (Eds.), Bioreactors for Waste Gas Treatment, Kluwer Academic

Publishers, Dordrecht, The Netherlands (2001), pp. 47-98

C. Kennes, M.C. Veiga

Fungal biocatalysts in the biofiltration of VOC polluted air

J. Biotechnol., 113 (2004), pp. 305-319

C. Kennes, H.H.J. Cox, H.J. Doddema, W. Harder

Design and performance of biofilters for the removal of alkylbenzene vapours

J. Chem. Technol. Biotechnol., 66 (1996), pp. 300-304

C. Kennes, M. Montes, M.E. López, M.C. Veiga

Waste gas treatment in bioreactors: environmental engineering aspects

Can. J. Civ. Eng., 36 (2009), pp. 1-9

Kennes et al., 2009b

C. Kennes, E.R. Rene, M.C. Veiga

Bioprocesses for air pollution control

J. Chem. Technol. Biotechnol., 84 (2009), pp. 1419-1436

B.T. Mohammad, M.C. Veiga, C. Kennes

Mesophilic and thermophilic biotreatment of BTEX polluted air in reactors

Biotechnol. Bioeng., 97 (2007), pp. 1423-1438

J.M. Morgan-Sagastume, S. Revah, A. Noyola

Pressure drop and gas distribution in compost based biofilters: medium mixing and composition effects

Environ. Technol., 24 (2003), pp. 797-807

B. Qi, W.M. Moe

Performance of low-pH biofilters treating a paint solvent mixture: continuous and intermittent loading

J. Hazard. Mater., 135 (2006), pp. 303-310

S. Raghuvanshi, B.V. Babu

Experimental studies and kinetic modeling for removal of methyl ethyl ketone using biofiltration

Bioresour. Technol., 100 (2009), pp. 3855-3861 
E.R. Rene, D.V.S. Murthy, T. Swaminathan

Performance evaluation of a compost biofilter treating toluene vapours

Process Biochem., 40 (2005), pp. 2771-2779

E.R. Rene, M.C. Veiga, C. Kennes

Performance of a biofilter for the removal of high concentrations of styrene under steady and non-steady state conditions

E.R. Rene, M.C. Veiga, C. Kennes

Experimental and neural model analysis of styrene removal from polluted air in a biofilter

J. Chem. Technol. Biotechnol., 87 (2009), pp. 941-948

J.W. Van Groenestijn, J.X. Liu

Removal of alpha-pinene from gases using biofilters containing fungi

Atmos. Environ., 36 (2002), pp. 5501-5508

J.W. van Groenestijn, W.N.M. van Heiningen, N.J.R. Kraakman

Biofilters based on the action of fungi

Water Sci. Technol., 44 (9) (2001), pp. 227-232

G. Vigueras, S. Arriaga, K. Shirai, M. Morales, S. Revah

Hydrophobic response of the fungus Rhinocladiella similis in the biofiltration with volatile organic compounds with different polarity

Biotechnol. Lett., 31 (2009), pp. 1203-1209

J.R. Woertz, W.N.M. van Heiningen, M.H.A. van Eeckert, N.J.R. Kraakman, K.A. Kinney

Dynamic bioreactor operation: effects of packing material and mite predation on toluene removal from off-gas

Appl. Microbiol. Biotechnol., 58 (2002), pp. 690-694 